IJER, 2 (1), 2017, 1 - 10

\title{
Model Pendidikan Karakter Komunitas Belajar Qaryah Thayyibah
}

\author{
Astri Hanjarwati ${ }^{1 *}$, Asep Jahidin ${ }^{2}$, Noerkamila² ${ }^{2}$ Siti Solehah ${ }^{2}$ \\ ${ }^{1}$ Prodi Sosiologi Fakultas Ilmu Sosial Humaniora UIN Sunan Kalijaga Yogyakarta, Jl. Laksda Adisucipto, \\ Caturtunggal, Kec. Depok, Kabupaten Sleman, Daerah Istimewa Yogyakarta 55281, Indonesia \\ ${ }^{2}$ Prodi Ilmu Kesejahteraan Sosial, Fakultas Dakwah dan Komunikasi, UIN Sunan Kalijaga Yogyakarta, Jl. Laksda \\ Adisucipto, Caturtunggal, Kec. Depok, Kabupaten Sleman, Daerah Istimewa Yogyakarta 55281, Indonesia
}

\begin{abstract}
Abstrak
Penelitian ini bertujuan untuk mengetahui model pendidikan karakter di Komunitas Belajar Qaryah Tayyibah (KBQT) yang berlokasi di Desa Kalibening, Kecamatan Tingkir, Kabupaten Slatiga, Propinsi Jawa Tengah. Penelitian ini menggunakan metode kualitatif-deskriptif. Metode pengumpulan data yang digunakan dalam penelitian ini adalah wawancara, observasi, dan dokumentasi, sedangkan pemeriksaan kebasahan data menggunakan teknik triangulasi. Hasil penelitian menunjukkan: (1)Kurikulum pembelajaran Komunitas Belajar Qoryah Thayyibah diserahkan kepada siswa, mereka bebas untuk menentukan apa yang ingin mereka pelajari, (2)Penentuan jam belajar di Komunitas Belajar Qoryah Thayyibah betul-betul diserahkan sepenuhnya kepada murid, (3)Kegiatan penting dan rutin dilakukan oleh para siswa adalah Tawasi, (4)Melakukan MOS di desa dan lingkungan dimana sekolah berada, (5)Kegiatan yang dibarengkan dengan masa otientasi siswa (MOS) pada awal tahun pembelajaran ketika siswa baru pertamakali masuk sekolah adalah salah satnya membersihkan sampah di lingkungan luar sekolah, (6) Dalam konteks dakwah bil hal Komunitas Belajar Qoryah Thayyibah juga dengan dengan demikian telah berkontribusi positif terhadap penyadaran masyarakat akan pentingnya memelihara dan berinteraksi dengan lingkungan.
\end{abstract}

Kata kunci : Pendidikan karakter, Komunitas belajar, Tawasi

\begin{abstract}
[Model of Character Education At Qaryah Thayyibah Learning Community]. This study aims at finding the model of character education model in Qaryah Tayyibah Learning Community (KBQT) located in Kalibening Village, Tingkir Subdistrict, Slatiga Regency, Central Java Province. This research used qualitative-descriptive method, where the study employed interview, observation, and documentation as data collecting techniques, and well as using triangulation as data trustworthiness technique. The results of the study are: (1) The learning curriculum of Qoryah Thayyibah Learning Community is given to the students, they are free to decide what they want to study, (2) The determination of study hours in Qoryah Thayyibah Learning Community is really left entirely to the students, (3) important and routine done by the students is Tawasi, (4) Conducting MOS in the village and the environment where the school is located, (5) The activity that is accompanied by the student's otientation (MOS) at the beginning of the learning year when the new student first enters school is one of the cleaning (6) In the context of dakwah bil the Community Learning Qoryah Thayyibah also thereby has contributed positively to the awareness of the community about the importance of maintaining and interacting with the environment.
\end{abstract}

Keywords : Character education, Community learning, Tawasi

\section{Pendahuluan}

Pendidikan diharapkan dapat meningkatkan kualitas dan derajat kehidupan lebih baik. Harapan besar disandarkan pada mekanisme ini. Konstitusi menetapkan salah satu tujuan utama negara pada bidang pendidikan adalah mencerdaskan kehidupan bangsa, bersifat universal untuk seluruh rakyat tanpa

\footnotetext{
*Penulis korespondensi

email: astri.hanjarwati@uinsuka.ac.id
}

kecuali (education for all). Selaras berjalannya pembangunan setengah abad lebih dari tonggak kemerdekaan. Ternyata pendidikan belum dapat dilaksanakan sesuai amanat konstitusi. Masih terdapatnya berbagai bias kepentingan, ketimpangan dan diskriminasi. Kualitasnya ditengarai belum memenuhi harapan sesuai yang disandarkan padanya. Sekolah yang ada terkesan belum mendidik muridnya untuk menumbuhkan pola berpikir kritis, berkemauan keras maju, inovatif serta kreatif. Kemudian hasilnya hanya mencetak mesin-mesin intelektual (Muarif, 2005). 


\section{IJER, 2 (1), 2017, 2}

Kualitas pendidikan di Indonesia secara makro sebenarnya tidak terlalu menggembirakan, walaupun juga terdapat pelajar yang memenangkan nobel. Hasil studi International Educational Achievement (IEA) menunjukkan kemampuan membaca siswa SD di Indonesia berada pada urutan ke-38 dari 39 negara yang diteliti. Sementara penelitian The Third International Mathematics and Science Study Repeat tahun 1999 menunjukkan kemampuan siswa SMP di bidang ilmu pengetahuan alam diurutan ke-32 dan untuk matematika di posisi ke-34 dari 38 negara yang diteliti diseluruh dunia (Djohar. 2003).

Hal yang paling memprihatinkan adalah adanya sederetan catatan buram pendidikan di Indonesia terkait dengan moralitas anak bangsa. Sebutlah diantaranya kasus contek masal yang terjadi di Surabaya beberapa waktu lalu, perilaku asusila anak-anak sekolah dasar, sampai perguruan tinggi yang semakin memperihatinkan, bahkan perilaku asusila guru terhadap muridnya.

Sebenarnya pemerintah telah menjadikan pendidikan karakter bangsa sebagai salah satu strategi dalam mewujudkan cita-cita pendidikan nasional. Bahkan belakangan ini pendidikan karakter seolah telah menjadi 'agama baru' bagi bangsa Indonesia. Sosialisasi dilakukan dimanamana. Ia menjadi tema yang cukup menarik untuk dibahas di berbagai kalangan, khususnya terkait dengan dunia pendidikan. Akan tetapi implementasi dari program ini masih sangat jauh dari harapan. Ada kesan secara konseptual pendidikan karakter masih ngambang dan 'diraba-raba'. Setelah kemudian di'meriah'kan lagi dengan adanya Sekolah Bertaraf Internasional (SBI) yang kemudian justru memberikan kesan mencederai dan kontra produktif dengan pendidikan karakter, dimana salah satu syaratnya adalah penggunaan bahasa Inggris sebagai bahasa pengantar proses belajar di sekolah. Belum lagi hal-hal lain yang mengarah pada indikasi komersialisasi pendidikan yang hanya menguntungkan beberapa pihak.

Disisi lain adanya 'trend' pendidikan karakter ini juga telah membuka peluang dan mendorong masyarakat membuat alternatif sekolah, disamping untuk mengatasi sulitnya aksesibilitas pendidikan juga merupakan sebuah reaksi sosial terhadap proses pendidikan yang belum mampu membangun karakter anak bangsa secara optimal. Hal ini dapat difahami karena gerakan sosial (social movement) berawal dari kondisi penuh kegelisahan, ketidakpuasan, keinginan dan harapan meraih tatanan kehidupan baru (Blumer,1946).

Sebagaimana yang terjadi di Desa Kalibening, Salatiga. Sebuah sekolah yang dilahirkan dari kegelisahan beberapa orang tua atas 'komersialisasi' pendidikan yang semakin tidak terjangkau masyarakat bawah. Untuk memasukkan anak ke sekolah lanjutan petama, sebagai bagian dari wajib belajar sembilan tahun, perlu mengeluarkan ratusan ribu rupiah. Maka berdirilah Komunitas Belajar Qaryah Thayyibah di Desa Kalibening, Salatiga. Tidak hanya itu saja, para pendirinya pun tidak hanya membangun sekedar sebuah alternative belajar, namun dari segi kualitas juga mereka usahakan untuk dapat setara dengan sekolah formal yang berada dikota. Untuk itu diberikan muatan lokal yang menjadi keunikan dari sekolah ini, seperti tawasi, pelaksanaan shalat berjama'ah dan shalat sunat dhuha, pelajaran bahasa Arab dan bahasa Inggris serta ketrampilan internet, kesenian, dan sebagainya.

Ternyata pengakuan terhadap keberadaan sekolah ini tidak perlu waktu lama. Nilai rata- rata ulangan murid Komunitas Belajar Qaryah Thayyibah jauh lebih baik daripada nilai rata-rata sekolah induknya, terutama untuk mata pelajaran Matematika dan Bahasa Inggris. Sekolah itu juga tampil meyakinkan, mengimbangi sekolah-sekolah negeri dalam lomba cerdas cermat penguasaan materi pelajaran di Salatiga. Sekolah itu juga mewakili Salatiga dalam lomba motivasi belajar mandiri di tingkat provinsi, dikirim mewakili Salatiga untuk hadir dalam Konvensi Lingkungan Hidup Pemuda Asia Pasifik di Surabaya. Pada tes kenaikan kelas satu, nilai rata-rata mata pelajaran Bahasa Inggris siswa Qaryah Thayyibah mencapai 8,86. Kelompok Belajar Qaryah Thayyibah juga maju dalam berkesenian. Di bawah bimbingan guru musik, Soedjono, anak-anak sekolah bergabung dalam grup musik Suara Lintang. Kebolehan anakanak itu dalam menyanyikan lagu mars dan himne sekolah dalam versi bahasa Inggris dan Indonesia bisa didengarkan ketika membuka alamat situs sekolah www.pendidikansalatiga.net. Grup musik anak-anak desa kecil itu telah mendokumentasikan lagu tradisional anak dalam kaset, MP3, maupun video CD album Tembang Dolanan Tempo Doeloe yang diproduksi sekaligus untuk pencarian dana. Seluruh siswa bisa bermain gitar, yang menjadi keterampilan wajib di sekolah itu. Sulit dibayangkan anak- anak petani sederhana itu masing-masing memiliki sebuah komputer, gitar, sepasang kamus bahasa Inggris-Indonesia dan Indonesia-Inggris, satu paket pelajaran Bahasa Inggris BBC di rumahnya.

Semua itu tidak digratiskan. Anak-anak memiliki semua itu dengan mengelola uang saku bersama-sama sebesar Rp 3.000 yang diterima anak dari orangtuanya setiap hari. Uang sebesar Rp 1.000 dipergunakan untuk mengangsur pembelian komputer. Untuk sarapan pagi, minum susu, madu, dan makanan kecil tiap hari Rp 1.000, sedangkan Rp 1.000 lainnya untuk ditabung di sekolah.

Tabungan sekolah itu dikembalikan untuk keperluan murid dalam bentuk gitar, kamus, dan lain-lainnya. Tidak mengherankan jika anak-anak dan orangtua mereka bangga dengan sekolah itu. Betapa tidak, di sekolah yang berdekatan dengan rumah di sebuah desa kecil mereka mendapatkan banyak hal yang tidak diperoleh di sekolah-sekolah 


\section{IJER, 2 (1), 2017, 3}

yang dikelola dengan logika dagang (Kompas, 2011).

Sistem pembelajaran yang diterapkan dikemas lebih dialogis dan andragogik. Siswa tidak segan dengan guru, guru bukanlah satu-satunya sumber belajar. Belajar tidak harus dikelas namun dapat juga dilakukan diluar kelas, seperti di kebun sekolah, di halaman. Sekolah pun dilaksanakan sambil bermain, ada yang bermain monopoli, bermain gitar, dan lain-lain. Sekolah menjadi hal yang menyenangkan. Padahal fenomena saat ini, sekolah TK pun sudah bukan lagi taman bermain, melainkan dihadapkan pada kewajiaban membaca, menulis dan berhitung.

Siswa Komunitas Belajar Qaryah Thayyibah pada awalnya hampir $90 \%$ adalah berlatar belakang keluarga sederhana. Pekerjaan orang tua/wali umumnya bekerja sebagai buruh, pedagang, petani dan lain sebagainya. Latar belakang ekonomi orang tua umumnya masih menengah ke bawah. Mereka hidup di lingkungan dan kultur desa, tapi secara admisnistratif termasuk wilayah Kota Salatiga. Kehidupan masyarakat di daerah ini terpaksa harus mengikuti ritme perkotaan sehingga nuansa perdasaan juga terkikis. Mulai dari pekerjaan sampai gaya hidup.Walaupun lahan pertanian di Kalibening belum banyak berkurang akan tetapi pengairan dan sistem irigasi menjadi kendala pengembangan sektor ini.

Fenomena mengenai sekolah Qaryah Tayyibah menarik untuk diteliti. Penelitian yang pernah dilakukan diantaranya adalah penelitian oleh Tri Agus Nugroho, tahun 2005 dengan judul "Alternatif Pembelajaran dari Kalibening". Penelitian ini lebih mengkaji mengenai model pembelajaran yang diterapkan di SLTP A Qaryah Tayyibah yaitu mengenai metode pengajaran, pembuatan kurikulum, interaksi siswa, guru dan pengelola sekolah serta masyarakat dan model evaluasi belajar yang dilakukan oleh sekolah. Dalam kajiannya ini Tri Agus Nugroho juga menarik benang merah antara kultur masyarakat Kalibening dengan ide pendirian SLTP A Qaryah Tayyibah (Nugroho, 2006).

Penelitian yang dilakukan oleh Tri Agus Nugroho, Astri Hanjarwati dan Desi Aryani dengan judul Memburu Pendidikan Malalui Sekolah Komunitas dan Internet : Studi atas Elaborasi SLTP A Qaryah Tayyibah dengan PT Indonet dalam fasilitasi pembelajaran bagi masyarakat. Penelitian ini dilakukan pada tahun 2006 dalam event Pekan Kreatifitas Mahasiswa Penelitian (PKMP) yang diselenggarakan oleh Dikti. Penelitian ini lebih mengkaji mengenai Corporate Responsibility PT indonet dalam bidang pendidikan. PT indonet yang merupakan perusahaan dalam bidang koneksi internet memberikan koneksi gratis kepada SLTP A Qaryah Tayyibah. Selain mengkaji bagaimana implementasi dari elaborasi tersebut, peneliti juga mengkaji mengenai manfaat internet bagi kemudahan pembelajaran dan bagaimana dampak setelah siswa menggunakan internet (Nugroho dkk, 2006).

Pendidikan secara luas dan umum sebagai usaha sadar yang dilakukan oleh pendidik melalui bimbingan, pengajaran dan latihan untuk membantu peserta didik mengalami proses pemanusian diri kearah tercapainya pribadi yang dewasasusila(Sudarminta,1990). Selain itu pendidikan adalah proses humanisasi (menjadikan seseorang sebagai manusia) dan humanisasi (pengembangan kemanusiaan manusia ) (Driyahara, 1990). Lebih lanjut dalam UU Nomor 20 Tahun 2003 tentang Sistem Pendidikan Nasional disebutkan sebagai usaha sadar dan terencana untuk mewujudkan suasana belajar dan proses pembelajaran agar peserta didik secara aktif mengembangkan potensi dirinya untuk memiliki kekuatan spiritual keagamaan, pengendalian diri, kepribadian, kecerdasan, akhlak mulia, serta ketrampilan yang diperlukan dirinya, masyarakat, bangsa dan negara.

Pendidikan dijadikan sebagai salah satu tujuan besar negara. Selanjutnya di legal formalkan dalam konsitusi, yang tertuang dalam pembukaan UUD 1945 dan Batang Tubuh pada pasal 31 ayat 1 - 5 (amandemen keempat) (amandemen UUD 1945, 2002). Tugas, harapan dan tujuan besar negara ini berbunyi “... mencerdaskan kehidupan bangsa ...”. Selanjutnya dijabarkan dalam pasal 31 ayat 1 berbunyi "Setiap warga negara berhak mendapat pendidikan".

Setiap pendidikan memiliki perpekstif pemikirannya masing-masing, oleh Henry Biroux dan Hronowitz (1985) dalam pengantar Mansour Fakih pada Ideologi-Ideologi Pendidikan karya William F O'Neil, menjadi tiga kelompok besar yaitu paradigma pendidikan Konservatif, Liberal dan Kritis (Muarif, 2005). Dimana secara singkat dapat di uraikan sebagai berikut:

Pertama, paradigma Pendidikan Konservatif (Tradisional). Merupakan penganut aliran filsafat perenialis dan esensialis yang bernuansa fatalistik serta anti perubahan. Menempatkan posisi manusia dalam keadaan pasif. Bahwa manusia berada di dunia hanya menjalankan perintah Tuhan. Segala sesuatu keadaan dan kejadian merupakan kehendak-Nya, manusia tinggal menjalankannya. Pendidikan konservatif hanya sebatas perwujudan dari ketidaksadaran manusia dalam menjalani hidupnya.

Kedua, paradigma Pendidikan Liberal. Mendasarkan pada modernitas dan kebebasan individu. Paradigma ini termasuk dalam aliran filsafat Progresif dan Eksistensialis. Dengan ciri rasionalitas empiris dengan nuansa posivistik. Yang dipelopori oleh rasionalisme Descartes dimana sangat mengedepankan kuasa akal pikiran manusia. Namun sekali lagi, paradigma pendidikan liberal meskipun mengakui keberadaan nilai-nilai transenden tetapi cenderung meninggalkannya. 


\section{IJER, 2 (1), 2017, 4}

Manusia kembali terjerambab dalam problem eksistensialisnya.

Ketiga, paradigma pendidikan kritis. Paradigma ini berkiblat pada aliran filsafat Eksistensialisme, Rekonstruksionalisme dan progresifme. Merupakan antitesis dari arus modernitas yang dipandang justru telah menghilangkan nilai-nilai humanitas. Dalam pandangan pendidikan kritis, setiap dominasi peran yang mengakibatkan penindasan itu tidak bisa ditolelir. Sebab bagaimana pun yang namanya penindasan adalah tidak manusiawi. Bertentangan dengan fitrah manusia pada lazimnya. Oleh karena itu penindasan merupakan musuh utama dalam pendidikan kritis.

Lingkungan memberi kontribusi dalam pendidikan anak baik sekolah maupun luar sekolah. Komponen itu: keluarga, sekolah, masyarakat, daerah dan geografisnya, teknologi dan masyarakat globalnya. Penyelenggaraan pendidikan yang cenderung ke arah hasil baik antara lain diukur dari (Djohar, 2003):

a. Pendidikan dirasa berguna bagi kepentingan anak. b. Nyaman bagi anak,

c. Muatan tranformatif bagi kehidupan anak baik individu maupun sosial.

d. Manusiawi. Selain itu siswa harus memiliki ketrampilan yang dapat benar-benar diandalkan. Kompetensi yang dimiliki paling tidak harus mampu untuk mewujudkan keinginan warga atas apa yang mereka jalani setiap harinya. Menurut Djohar (2003) salah satu panduan untuk menentukan kompetensi (Djohar,2003) adalah:

a. Karakteristik anak dan Situasi lingkungan

b. Situasi Sosial - Budaya Masyarakat

c. Tingkat perkembangan Iptek

Karakteristik anak dapat dipengaruhi oleh lingkungannya, karena dalam proses belajar tersebut mereka juga mulai mendeskripsikan apa yang ada di sekitar mereka. Situasi sosial dan budaya masyarakat pun dapat menjadi ruang belajar tersendiri bagi anak-anak karena mereka merupakan bagian di dalamnya serta seyogyanya mempunyai kewajiban moral untuk mengenal keadaan masyarakat pada tempat tinggal mereka sendiri. Selain itu Iptek menjadi sarana penting dalam belajar untuk menunjang proses transfer knowledge dari dunia luas ke alam pikiran mereka. Iptek merupakan sarana agar anak-anak yang belajar mempunyai kemampuan lebih untuk menyongsong zaman yang semakin modern.

Seorang kritikus radikal pendidikan Ivan Illich memberikan sebuah tawaran untuk mengembalikan esensi pendidikan dengan "jaringan pendidikan (educational web)". Ide pokoknya adalah memperluas kesempatan seseorang untuk belajar melalui saluran-saluran sumber pembelajaran yang ada. Terdapat empat saluran pendidikan (Illich, 2000) yaitu; a. Jasa referensi pada objek-objek pendidikan. Pemanfaatan objek yang tersedia secara optimal untuk belajar.

b. Pertukaran keterampilan. Intinya adalah belajar dari siapa saja untuk bisa memperoleh informasi dan pengetahuan.

c. Mencari teman sebaya yang cocok.

d. Jasa referensi pada pendidik-pada-umumnya. Memunculkan panggilan untuk menjadi pendidik lepas.

Membangun masyarakat dari wacana berpikir yang statis tradisional menjadi dinamis rasional adalah aktivitas pendidikan. Bahkan keseluruhan proses kegiatan pembangunan masyarakat desa/kota -rural and urban community development- itu memerlukan "community education". Bentuknya bervariasi, mulai pendidikan formal, nonformal dan informal, penyuluhan pembangunan, komunikasi pembangunan, pendidikan kesejahteraan keluarga, demokrasi, pendidikan keterampilan, dan lain-lain. Kata kunci dari tujuan pendidikan adalah adanya perubahan perilaku (behavior). Komponen-komponen perilaku ini selalu merujuk kepada apa yang telah diketahui atau dipahami oleh warga belajar/peserta didik (knowledge), apa yang dapat mereka lakukan (skills), apa yang mereka pikirkan (attitudes) dan secara nyata apa yang mereka kerjakan (action).

\section{Konsep Pendidikan Karakter}

Mimpi orang tua terhadap anaknya pada saat awal mereka masuk dalam lembaga pendidikan adalah kelak anak-anak dapat menjadi anak yang baik dan pintar. Menjadi anak yang baik mengasumsikan ia menjadi sosok yang mulai, berakhlaq karimah, mentradisikan nilai-nilai luhur budaya bangsa dan agama, dan sebagainya yang terangkum dalam nilai-nilai moral. Sedangkan menjadi anak pintar, tercermin dalam prestasi hasil belajar yang bagus, kemampuan menguasai mata pelajaran, menjadi juara kelas, dan berbagai prestasi lainnya. Akan tetapi, bila orang tua ini harus memilih, menjadi anak baik atau anak pintar, maka dapat dipastikan mereka lebih memilih memiliki anak yang kurang pintar tetapi baik, dari pada memiliki anak pintar tetapi tidak baik.

Seorang filsuf Yunani bernama Aristoteles mendefinisikan karakter yang baik sebagai kehidupan dengan melakukan tindakan-tindakan yang benar sehubungan dengan diri seseorang dan orang lain (Lickona, 2012). Karakter, menurut pengamatan seorang filsuf kontemporer bernama Michael Novak, merupakan 'campuran kompatibel dari seluruh kebaikan yang diidentifikasi oleh tradisi religius, cerita sastra, kaum bijaksana, dan kumpulan orang berakal sehat yang ada dalam sejarah Pada akhirnya Lickona menyimpulkan bahwa, karakter terdiri dari nilai operatif, nilai dalam tindakan (Lickona, 2012). 


\section{IJER, 2 (1), 2017, 5}

Karakter yang demikian memiliki tiga bagian yang saling berhubungan; pengetahuan moral, perasaan moral dan perilaku moral. Karakter yang baik terdiri dari mengetahui yang baik, menginginkan hal yang baik, dan melakukan hal yang baik-kebiasaan dalam cara berpikir, kebiasaan dalam hati, dan kebiasaan dalam tindakan. Ketiga hal ini diperlukan untuk mengarahkan suatu kehidupan moral; ketiganya ini membentuk kedewasaan moral (Lickona, 2012).

Ketiga hal tersebut, yakni pengetahuan moral, perasaan moral dan tindakan moral merupakan komponen karakter. Ketiga komponen tersebut merupakan satu kesatuan yang saling berkait berkelindan antara satu dengan lainnya. Ketiga komponen karakter inilah yang digunakan untuk mengkerangkai teori dari penelitian ini.

Lebih jauh Lickona mengidentifikasi kualitas moral-ciri-ciri karakter-yang membentuk pengetahuan moral, perasaan moral, dan tindakan moral tersebut. Pengetahuan moral, terdiri dari kesadaran moral, mengetahui nilai-nilai moral, memiliki perspektif, memiliki alasan moral, membuat keputusan dan berpengetahuan. Perasaan moral, mencakup berhati nurani, percaya diri, berempati, menyukai kebaikan, dapat mengontrol diri, dan rendah hati. Sedangkan tindakan moral, mencakup berkemampuan, memiliki kemauan, dan memiliki kebiasaan baik).

\section{Pendidikan Karakter di Sekolah}

Dewasa ini berbagai kalangan semakin menyadari pentingnya pendidikan nilai/karakter diajarkan di sekolah. Beberapa dekade sebelumnya, memang pernah dilontarkan bahwa sekolah tidak memiliki kewajiban untuk mengajarkan nilai-nilai (karakter). Kebutuhan akan pendidikan nilai ini terasa sangat mendesak, mengingat gambaran carutmarutnya moralitas anak bangsa. Kegelisahan akan hal ini tidak hanya dirasakan oleh para orang tua, melainkan berbagai elemen masyarakat juga turut prihatin atas fenomena ini. Kiranya inilah yang menjadi salah satu alasan mengapa pendidikan nilai/karakter perlu diajarkan di sekolah. Apabila sekolah ingin mengembangkan karakter dalam proses pendidikannya, maka sekolah harus menyediakan lingkungan moral yang menentukan nilai-nilai yang baik dan menyimpannya di dalam hati nurani setiap orang. Diperlukan waktu yang lama bagi sebuah nilai untuk menjadi sebuah kebaikan-untuk berkembang dari kesadaran intelektual semata menjadi kebiasaan pribadi untuk berpikir, merasa, dan bertindak yang membuatnya menjadi prioritas yang berfungsi. Seluruh lingkungan sekolah, kebudayaan sekolah, harus mendukung pertumbuhan tersebut (Lickona, 2012).

Dengan demikian, upaya mengembangkan pendidikan karakter di sekolah mensyaratkan adanya kepaduan antara berbagai unsur yang terkait dalam pendidikan, baik yang terkait secara langsung maupun tidak langsung dengan sekolah. Termasuk dalam hal ini adalah kurikulum pendidikan, baik intra kurikuler maupun extra kurikuler serta lingkungan keluarga dan masyarakat sekitar sekolah.

Karakter-karakter baik apa yang seharusnya dikembangkan di sekolah? Secara eksplisit, Bagus Mustakim menginventarisir delapan karakter emas yang harus dikembangkan di sekolah, yakni etos spiritual, etos mutu, demokratis, multikultural, kecerdasan kritis, peduli lingkungan, berwawasan maritim, dan tanggung jawab global (Mustaqim, 2011). Sementara itu, Lickona hanya mengidentifikasi dua karakter baik yang menjadi inti (corevalues) dari karakter baik ini, yakni rasa hormat (respect) dan tanggung jawab (Lickona, 2012).

Respek adalah menunjukkan rasa hormat pada seseorang atau sesuatu yang berharga. Hal ini termasuk respek pad diri sendiri, yaitu respek terhadap hak-hak dan martabat manusia, dan respek pada lingkungan yang menyokong semua kehidupan. Respek menopang semua sisi moral. Selain itu, respek pun menjaga kita untuk tidak merugikan apa yang harus kita hargai. Adapun tanggung jawab adalah sisi aktif dari moral. Tanggung jawab termasuk menjaga diri sendiri dan orang lain, memenuhi kewajiban, berkontribusi terhadap masyarakat kita, meringankan beban, dan membangun sebuah dunia yang lebih baik (Lickona, 2012).

Kesemua itu tentu saja tidak dapat diraih tanpa disertai strategi-strategi tertentu yang didesain sedemikian rupa sehingga proses internalisasi nilainilai dalam pikiran (pengetahuan moral) dan perasaan (perasaan moral) murid dapat membimbing dan menggerakkan mereka untuk bertindak (tindakan moral). Ada sejumlah strategi yang ditawarkan Lickona dalam hal ini, yakni suatu strategi yang disebutnya sebagai "Strategi Berbasis Sekolah', pendekatan komprehensif terhadap nilai dan Pendidikan Karakter. Strategi ini mencakup 1) Pengasuhan Lebih dari ruang kelas, yang di dalamnya terdapat strategi-strategi kelas. Strategi ini sangat ditentukan oleh peran guru sebagai pengasuh, model dan mentor, serta tergantung pada kemampuan guru dalam menciptakan sebuah komunitas kelas yang bermoral. 2) Menciptkan Budaya Moral yang Positif di Sekolah, dan yang ke 3) Sekolah, Orang Tua dan Masyarakat Sebagai Mitra.

Diagram 1 Komponen Karakter yang Baik 


\section{IJER, 2 (1), 2017, 6}

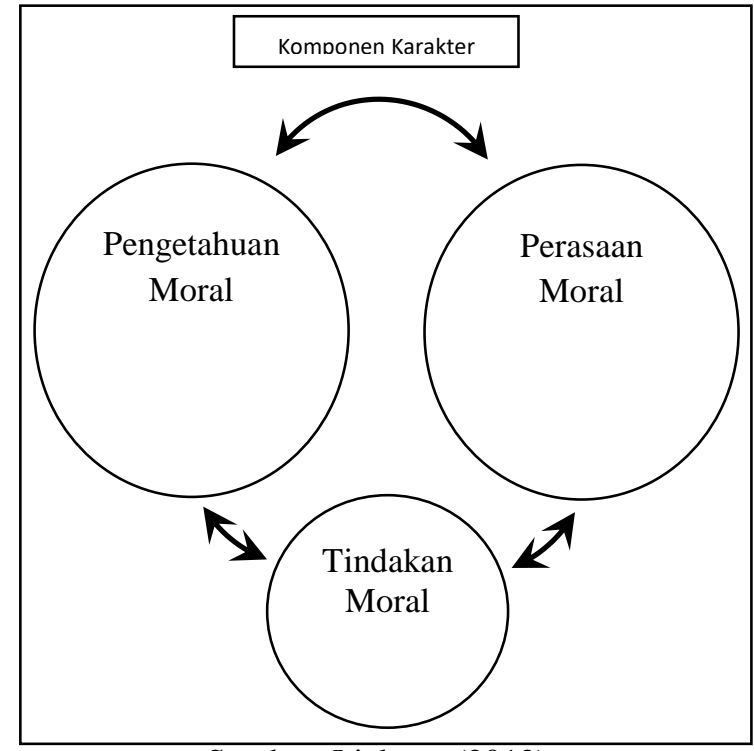

Sumber: Lickona (2012)

Gambar ketiga komponen karakter yang baik diatas, menunjukkan adanya saling keterhubungan dan memengaruhi satu sama lain. Masing-masing komponen tidak bekerja sendiri-sendiri melainkan bekerja sama dengan komponen yang lain.

\section{Metode}

Penelitian ini menggunakan metode deskriptif kualitatif. Cara pengambilan data dengan wawancara mendalam, observasi, dokumentasi dan triangulasi. Unit analisis dalam studi ini adalah Komunitas Belajar Qaryah Tayyibah. Dengan menggunakan analisis stakeholder, maka pihakpihak yang terkait dalam kegiatan belajar adalah: (1)Siswa, (2)guru, (3) pengelola, (4) masyarakat (orang tua siswa). Dengan demikian informan dalam penelitian adalah keempat jenis stakeholder tersebut. Pada level siswa akan dikaji mengenai bagaimana proses pembelajaran dan materi pembelajaran yang diterapkan di Komunitas Belajar Qaryah Tayyibah yang mampu berperan kuat dalam pembentukan karakter siswa. Pada level Pengelola akan di kaji bagaimana Komunitas Belajar membentuk karakter siswa melalui model pembelajaran atau kurikulum yang di buat oleh pengelola. Pada level guru akan dikaji mengenai bagaimana pembelajaran di kelas dan bagaimana pengaruhnya rutinitas pembelajaran pada pembentukan karakter siswa. Pada level orangtua (masyarakat) dikaji mengenai bagaimana perbedaan karakter siswa sebelum dan sesudah belajar di Komunitas Belajar Qaryah Tayyibah.

\section{Temuan dan Pembahasan}

Penelitain ini dilatar belakangi oleh rasa prihatin dan kegelisahan atas hal-hal negitif yang terjadi di lingkungan pendidikan sekolah seperti bulying serta tawuran, nyontek bersama serta perilaku negatif lainnya di lingkungan sekolah. Oleh sebab itu penelitian ini diharapkan dapat ikut memberikan sumbangan positif terhadap perbaikan dan penyelesaian masalah yang dihadapi oleh dunia pendidikan tersebut. Khususnya pada pembangunan karakter peserta didik di sekolah.

Pada sekolah formal yang biasa pada umumnya kita temui, biasanya untuk menjadi dan diakui sebagai seorang siswa di sekolah, maka seseorang harus diasosiasikan dengan menenteng tas rangsel, membawa sejumlah buku serta tidak lupa mengenakan seragam dengan segala atributnya apabila hendak dikatakan dan diakui bahwa dia sedang menjadi siswa atau belajar. Jangan sampai terpikirkan oleh seorang anak didik untuk tidak bersepatu ketika datang di kelas. Siswa harus duduk menghadap papan tulis menunggu guru untuk belajar dan diajar.

Pembelajaran dilalui anak-anak tanpa banyak bergerak karena akan mengganggu pengajar dalam mengajar. Dalam beberapa kasus disertai dengan guru yang menakutkan bagi muridnya. Murid mengerjakan apa yang diperintahkan oleh gurunya dan tidak boleh menuruti keinginan hati untuk bermain atau mengerjakan hal lain. Pada sebagian besar sekolah, kelas hanyalah yang difahami sebagai sebuah ruangan yang dibatasi oleh dinding jendela serta pintu, diluar itu bukanlah kelas untuk melakukan aktifitas pembelajraan.

Lain halnya murid Komunitas Belajar Qaryah Thayyibah (KB QT) ketika menikmati belajar bersama di kelasnya, hanya kegembiraan yang ada saat itu. Proses belajar Komunitas Belajar Qaryah Thayyibah (KB QT) ini didominasi keceriaan dan suasana bercanda tanpa terbebani materi kurikulum formal. Mereka para murid itu dibebaskan untuk membuat kurikulumnya sendiri sesuai dengan apa yang mereka butuhkan.

Pembelajaran untuk memenuhi jatah kurikulum formal bisa mereka kebut satu bulan sebelum ujian penyetaraan atau uijan nasional. Harihari biasa dipergunakan siswa untuk belajar dari lingkungannya, sebagian kurikulum dan segala yang ingin mereka ketahui kemudian disepakati bersama sama seluruh anggota kelas dibawah bimbingan guru pendamping.

Tersirat keceriaan ketika anak-anak ini sedang asik bermain, riuh rendah dan sambil berteriak-teriak selama proses belajar berlangsung, kemudian berubah menjadi serius lalu tersenyum setelah memahami persoalan mereka. Siswa saling bertukar ide dan bersendau gurau dengan teman, guru atau siapa pun tanpa harus "malu-malu". Belajar tidak harus dilakukan anak dengan duduk manis, tangan di atas meja dan sambil pasang telinga mendengarkan suara merdu sang guru mereka. Murid bebas bergerak dari kursi satu ke satunya, bahkan mereka dapat duduk seenak badan yang penting belajar tetap berjalan. Ruangannya ada banyak sekali bahkan ada yang tidak berdinding sama sekali yaitu lingkungan desanya sendiri. Mengingat semua tempat adalah kelas atau kelas terdapat di mana saja asalkan pembelajaran siswa 


\section{IJER, 2 (1), 2017, 7}

dapat berlangsung. Kadang kala mereka belajar di taman dengan melapangkan tikar kemudian belajar pun dimulai.

Komunitas Belajar 'Qaryah Thayyibah' (KBQT) membangun model pembelajaran yang dapat membangun karakter peserta didiknya sehingga memiliki karakter yang kokoh dan 'khas'. Pembahasan akan dimulai dari nilai-nilai inti yang ditanamkan di sekolah ini. Karena sesungguhnya kekuatan karakter individu dibangun dari adanya nilai-nilai inti yang diyakini oleh individu tersebut. Pembahasan berikutnya menggunakan kerangka Lickona untuk mengurai karakter baik yang dapat dikembangkan dalam diri individu. Dan pada bagian terakhir dari bab ini, diuraikan peran guru, pendamping dan masyarakat sebagai bagian yang turut memberikan kontribusi dalam pembentukan karakter peserta didik di KBQT.

\section{a. 'Core Values'}

Nilai-nilai inti atau core values merupakan nilai-nilai dasar yang melandasi berbagai prinsipprinsip etik yang ditanamkan pada peserta didik. Terdapat dua nilai yang menjadi core values di sekolah ini, yakni "kepercayaan tanpa syarat" dan "beri manfaat, jangan merugikan orang lain".

Siswa-siswi KBQT memperoleh kepercayaan yang penuh, sebuah kepercayaan tanpa syarat. Implementasi dari nilai ini, mereka memperoleh wewenang untuk mengatur segala sesuatunya, termasuk memenej proses belajar mereka sendiri. Sebutlah misalnya, tentang materi pembelajaran. Umumnya sekolah-sekolah yang termasuk kategori 'bagus', mereka memiliki kurikulum yang telah disusun secara sistematis. Hal demikian tidak ditemukan di KBQT. Kurikulum mereka adalah keinginan dan atau kebutuhan siswa-siswi sendiri. Bila mereka menginginkan belajar tentang kesehatan gigi, maka yang akan dipelajari adalah tentang kesehatan gigi. Mereka pun mencari dokter gigi untuk langsung belajar padanya. Mereka mengontak sendiri gurunya, mengatur sendiri jadwalnya, waktu, tempat dan lain sebagainya.

Untuk evaluasi di Komunitas Qaryah Thayyibah tidak ada evaluasi, yang ada adalah Gelar Karya yang diadakan setiap bulan. Dalam acara gelar karya semua siswa menampilkan karya yang dibuat sesuai dengan minat dari siwanya. Semua siswa di Komunitas Belajar Qaryah Thayyibah mempunyai minat yang berbeda-beda, dan mempunyai semangat kebersamaan dan kekeluargaan untuk saling membantu mewujudkan impian mereka.

Selain menampilkan gelar karya untuk setiap bulannya, evaluasi mengenai belajar siswa adalah dengan membuat target per enam bulan bagi setiap siswa. Masing- masing siswa mempunyai target sesuai dengan bidang yang menjadi minatnya dan dievaluasi setiap enam bulan. Siswa Komunitas Belajar Qaryah Thayyibah, mempunyai minat yang berbeda-beda ada yang menyukai desain, computer, IT, menulis, kesehatan, dan lain-lain.

Demikian pula suatu ketika mereka punya ide, gagasan, ingin mengadakan sebuah kegiatan, misalnya. Segala sesuatunya mereka disain sendiri. Mulai dari penyusunan proposal, menyusun budget anggaran, bahkan 'menjual' proposal-pun mereka sendiri yang melakukannya. Bayangkan, anak-anak usia SLTP mengorganisir kegiatan mereka sendiri! Sebuah kepercayaan tanpa syarat...!

Setiap siswa dan siswi ditekankan dalam kesehariannya agar dapat memberi manfaat dan sebaliknya, jangan sampai merugikan orang lain. Dengan nilai-nilai inti yang ditanamkan kepada seluruh siswa-siswi tersebut, dapat membangun berbagai prinsip-prinsip etik yang selanjutnya dapat menggerakkan para siswa-siswi KBQT ini sehingga terbangun karakter yang kokoh.

\section{b. Proses Pembentukan Karakter Melalui Tawasi}

Tawasi adalah aktifitas harian yang wajib diikuti oleh seluruh siswa, didalamnya berisi aktifitas yang rutin yaitu tadarus al'Quran dan aktifitas tambahan yang bentuknya selslau disesuaikan dengan kebutuhan siswa pada setiap harinya

Tawasi merupakan program paling penting dalam aktifitas satu hari meskipun diwajibkan oleh sekolah namun para siswa tetap memiliki peluang untuk menentukan persoalan apa yang akan meeka bahas di dalam pertemuan tersebut, hal ini memungkinkan siswa untuk memberikan pandangan mereka atau usul mengenai aktifitas yang akan di tambahkan di dalam kegiatan tawasi. Karakter yang baik, terbangun dari tiga unsur karakter yang saling mempengaruhi satu sama lain, yakni pengetahuan moral, perasaan moral dan tindakan moral. Pengetahuan moral yang terinternalisasikan dalam wilayah pikir seseorang, belum dapat mendorong seseorang untuk melakukan tindakan moral tertentu sesuai dengan pengetahuan moral yang dimilikinya. Hal ini karena pengetahuan tersebut belum terinternalisasikan ke dalam perasaan individu. Sementara itu, suatu tindakan moral akan dapat terjadi manakala seseorang individu telah memiliki pengetahuan dan perasaan moral sekaligus.

\section{c. Peran Guru, Pendamping dan Masyarakat dalam Pembentukan Karakter}

Dalam konsep Lickona, sebagai upaya menanamkan karakter pada siswa-siswi di sekolah, hendaknya guru, pendamping dan masyarakat dapat menjadi mitra terbaik sekolah. Demikian pula di KBQT. Ada kemitraan yang terjalin diantara tiga unsur ini, yakni guru, pendamping dan masyarakat.

Guru dalam konsep KBQT adalah mereka yang memiliki keahlian dalam bidang tertentu. Keahlian yang sudah mendapat pengakuan dari masyarakat. Yang dimaksud ahli disini adalah 


\section{IJER, 2 (1), 2017, 8}

profesional di bidangnya, misalnya, guru bagi pelajaran tentang kesehatan adalah dokter, guru bagi pelajaran olahraga adalah atlet, guru bagi pelajaran seni adalah seniman, dll. Sehingga guru mereka adalah betul-betul merupakan seorang ahli di bidangnya. Guru bagi siswa-siswi ini adalah sumber ilmu, tempat bertanya dan mengembangkan kemampuan. Siswa-siswi tak akan enggan bertanya kepada guru mereka tentang hal-hal yang ingin diketahuinya.

Bagaimana para profesional itu bisa hadir dan mengajar di KBQT? Jangan dibayangkan mereka belajar dengan tertib di dalam kelas, karena proses pembelajaran belum tentu ada di dalam kelas. Proses belajar berlangsung tergantung dari kesepakatan yang diambil diantara guru dan peserta didik. Seketika peserta didik menemukan sesuatu hal yang ingin dipelajari, kemudian berhasil menghubungi profesional di bidangnya, maka selanjutnya kesepakatan diantara mereka dibuat. Kapan, dimana, berapa lama mereka akan belajar. Sehingga belum tentu para 'guru' ini yang menyambangi sekolah mereka, bisa jadi para peserta didik ini yang menemui guru mereka, atau bahkan mereka bersepakat untuk mengadakan pertemuan di suatu tempat tertentu.

Untuk tema-tema tertentu, para profesional ini cukup dihadirkan melalui media internet. Para peserta didik ini telah mahir dan terampil mengakses internet. Dengan mudag mereka dapat mencari apa yang mereka butuhkan. Termasuk mencari 'guru' yang mereka butuhkan. Sehingga pemaknaan 'guru' bagi peserta didik KBQT adalah siapapun dan apapun yang dapat menjadi sumber belajar, itulah 'guru' mereka.

Ibarat dalam sebuah keluarga, pendamping layaknya seorang kakak untuk para peserta didik. Mereka senantiasa mendampingi para peserta didik ini belajar. Peran mereka sebagai fasilitator, yang memfasilitasi, mendukung dan memperlancar proses belajar.

Masyarakat sekitar KBQT turut ambil bagian yang tidak sedikit dalam pembentukan karakter peserta didik. Bahkan pada awal pembangunan KBQT ini, masyarakat sendirilah yang bersamasama membangun sekolah. Mereka berkontribusi besar dalam mensuskeskan putra-putri Kalibening ke dalam sejumlah prestasi.

Rumah-rumah penduduk di sekitar KBQT merupakan tempat tinggal yang digunakan peserta didik yang beasal dari luar daerah Kalibening. Ya, sejak KBQT ini meraih prestasi di berbagai bidang, terutama bahasa Inggris dan Matematika, terjadi perubahan struktur peserta didik, sehingga tidak hanya berasal dari sekitar Kalibening, melainkan terus berkembang berkembang dan pada saat ini terdapat 54 peserta didik yang berasal dari luar daerah Kalibening. Peserta didik inilah yang kemudian tinggal di rumah-rumah penduduk sekitar kampung Kalibening. Uniknya, bapak-ibu kost ini mengatasnamakan 'wali angkat' bukan bapak/ibu kost. Menurut mb Nurul, istilah ini digunakan untuk menghindari pola atau praktik kapitalis, suatu relasi yang menggambarkan bahwa peserta didik membutuhkan tempat tinggal (kost) dan ibu/bpk kost membutuhkan uang. Dengan istilah 'wali angkat', memberikan kesan lebih humanis, lebih dekat lebih bersahabat dan bersaudara.

Murid-murid sejak dini ditanamkan untuk memiliki rasa kebersamaan antar mereka sendiri dan masyarakatnya. Bahwa kepintarannya kemudian tidak hanya digunakan sendiri tetapi bagaimana kemampuan itu mampu membantu teman-temannya. Pembelajaran bersama ini dilakukan untuk mengurangi ketergantungan siswa dengan seorang guru. Anak-anak diharapkan mempunyai Komunitas belajar yang solid dalam hal ini adalah kelas. Mereka akan belajar sendiri tanpa bergantung dengan guru namun saling belajar antar mereka.

Tidak bergantung pada guru mulai ditanamkan kepada anak sejak memasuki kelas satu.

Kelas satu, merupakan proses peralihan dari SD (Sekolah Dasar) ke SLTP (Sekolah Lanjutan Tingkat Pertama) yang dirasa akan cukup berat bagi si anak. Sewaktu mereka belajar di SD terbiasa dengan semuanya diperintah, diatur dan ditata di mana merupakan makanan sehari-hari baginya. Belajar pun disuruh dan ada waktunya bagi mereka dari jam 7 hingga jam 13.30 siang. Siswa dilarang keras untuk ramai atau bercanda saat sedang belajar. Mendebat atau membantah guru adalah hal yang tabu untuk dilakukan bahkan untuk dipikirkan saja jangan sampai. Pelajaran semuanya menunggu guru, apa yang diberikan itulah tugas wajib untuk mempelajarinya dan sebagainya.

Kebersamaan, gotong royong, guyub dan saling menghormati merupakan sebuah harta dari bangsa ini. Namun nilai-nilai tersebut lambat laun mulai terkikis dengan mengatasnamakan kebutuhan dan kepentingan. Semua cara dilakukan untuk mencapai sebuah kesejahteraan yang bersifat kapitalistik. Masyarakat sekarang ini lebih condong memiliki corak sosial yang individualistik serta mengedepankan egonya. Berdiri di atas penderitaan orang lain sudah tidak lagi merupakan hal baru di Indonesia ini. Bahkan jika bisa, bagaimana caranya untuk menambah penderitaan-penderitaan tersebut, mengingat dengan bertambahnya penderitaan maka proyek baru terbuka. Pemanfaatan atas ketidakmampuan seseorang dan masyarakat sering dilakukan oleh para pekerja kemiskinan kita (Nugroho, 2005). Kemunculan modernisasi membawa dampak yang cukup hebat dalam perhelatan kehidupan masyarakat Indonesia. Modernisasi diwarnai oleh semangat kompetitif, efisiensi serta menjunjung rasionalitas dengan pondasi filsafat Rasionalistis-materialismenya. Pemikiran itu membuat berbagai perubahan di dalam masyarakat di mana semuanya dinilai secara materi: menguntungkan, sedikit menguntungkan dan 


\section{IJER, 2 (1), 2017, 9}

tidak menguntungkan sama sekali. Ainurrofiq berpendapat bahwa dalam proses modernisasi, struktur institusional yang pincang dan menindas tidak punah. Ia bahkan semakin kuat dan kukuh dengan hadirnya rasionalisasi, efisiensi, liberalisasi, hukum pasar dan masih diperkuat dengan feodalisme (Ainuroffiq, 2003).

Kompetisi dan pemikiran rasionalmaterialisme tidak terbendung juga memasuki dunia pembelajaran sekolah. Mekanisme itu tidak hanya sebagai sarana pembelajaran semata, namun juga menjadikan arena kompetisi juara dan tidak juara. Anak yang pintar adalah yang mempunyai rangking top ten di kelasnya, selebihnya termasuk anak yang bodoh. Kadang sekolah dipakai sebagai ajang untuk kontes para orang tua di dalam mendidik anaknya, mulai dari bimbingan belajar, kursus, privat dan lain-lainnya. Masyarakat bahkan berkompetisi atas sarana tranportasinya, pakaian seragamnya, HP serta sumbangan terhadap sekolah menjadi status sosial selain bersekolah itu sendiri. Sebagaimana pendapat Djohar bahwa dewasa ini sekolah tidak dijadikan sebagai tempat anak melatih diri, menampilkan dirinya untuk berbuat sesuatu dan mendapatkan koreksi bahwa ia salah dan benar, berbuat baik atau tidak baik, akan tetapi sekolah dijadikan sebagai panggung pentas untuk memperoleh juara (Djohar, 2003).

Bukan sebuah hal yang mengherankan apabila kemudian pembelajaran sekolah memunculkan sebuah wacana tentang Kanibalisme Intelektual. Artinya bahwa seseorang yang pintar kemudian memanfaatkan yang kurang dan belum pintar, bahkan yang tidak pintar. Pengetahuan dikuasai oleh seseorang untuk mengusai orang lain berdasarkan tujuan pribadinya. Pembelajaran sekolah selalu mengajarkan bagaimana caranya agar dapat memupuk keuntungan sebesar-besarnya dari modal yang sekecil-kecilnya. Tidak pernah bagaimana seseorang itu dapat memperoleh keuntungan namun secara fair dan tidak merugikan orang lain, syukur dapat menguntungkan bagi orang lain. Kebijakan-kebijakan yang dikeluarkan pemerintah kadang kala memposisikan kaum marginal sebagai bagian yang tidak tercakup dalam sebuah kebijakan. Kebijakan itu dilakukan untuk kepentingan diri sendiri, tidak pernah memikirkan masyarakat banyak yang membutuhkan pengayoman dari para "orang pintar" tadi. Dijelaskan oleh Freire bahwa sering terjadi di mana para orang tertindas lantas mewarisi apa yang telah dimiliki dan dilakukan oleh penindasnya. Bayangan kaum penindas mereka sebelumnya masih melekat dalam diri mereka (Freire,1991). Hal ini juga diwarisi dan diwariskan melalui sistem pembelajaran yang telah dianut dengan berasaskan pada ajaran liberalisme dan rasionalis-materialis.

\section{Kesimpulan}

Pengelola Komunitas Belajar Qaryah Thayyibah menerapkan pola pendidikan yang apabila dibandingkan dengan sekolah formal sangat berbeda yaitu segala hal berpusat pada siswa. Beberapa hal penting yang biasanya pada sekolah sekolah lain di lakukan oleh pengelola/guru tetapi di Kelompok Belajar Qoryah Thayyibah hal tersebut dilakukan oleh siswa diantaranya adalah :

Pertama, kurikulum pembelajaran Komunitas Belajar Qoryah Thayyibah diserahkan kepada siswa, mereka bebas untuk menentukan apa yang ingin mereka pelajari, bahannya darimana, kapan belajarnya termasuk menentukan jam serta harinya. Pengelola sekolah dalam hal ini berperan sebagai fasilitator untuk memenuhi kebutuhan para siswa. Pengelola membuat peraturan umum, salah satu peraturan misalnya sekolah mewajibkan untuk setiap murid harus berkarya, apapun karyanya.

Kedua, Penentuan jam belajar di Komunitas Belajar Qoryah Thayyibah betul-betul diserahkan sepenuhnya kepada murid, para murid dalam satu kelas akan berdiskusi dan membuat kesepakatan diantara mereka sendiri, guru pembimbing kelasa yang berperan sebagi fasilitator akan mengawal jalannya diskusi tetapi dia tidak mengendalikan. Guru fasilitator hadir untuk memastikan para siswa menghasilkan kesepakatan diantara mereka sendiri. Kebebasan lainnya adalah mengenai tempat belajar, penggunaan seragam, ekstrakulikuler dan pembiayaan sekolah.

Ketiga, kegiatan penting dan rutin dilakukan oleh para siswa adalah Tawasi. Tawasi (sebuah aktifitas harian yang wajib diikuti oleh seluruh siswa, didalamnya berisi aktifitas yang rutin yaitu tadarus al'Quran dan aktifitas tambahan yang bentuknya selalu disesuaikan dengan kebutuhan siswa pada setiap harinya). Tawasi yang merupakan program paling penting dalam aktifitas satu hari meskipun diwajibkan oleh sekolah namun para siswa tetap memiliki peluang untuk menentukan persoalan apa yang akan meeka bahas di dalam pertemuan tersebut, hal ini memungkinkan siswa untuk memberikan pandangan mereka atau usul mengenai aktifitas yang akan di tambahkan di dalam kegiatan tawasi.

Keempat, melakukan MOS di desa dan lingkungan dimana sekolah berada. Yaitu di Desa Kalibening. Dalam melakukan MOS siswa biasanya dikenalkan dengan wilayah dimana sekolah berada, tidak hanya secara geografis akan tetapi secara sosial siswa dikenalkan dengan kehidupan dan pola serta etika keseharian yang berlaku di masyarakat setempat. Dengan demikian siswa akan mengenal lebih baik lingkungan tempat mereka berada dan hidup keseharian. Siswa tidak lepas dari irama sentral masyarakat yang lebih besar. Dalam jangka panjang kegiatan seperti ini serta pembiasaan yang dilakuakna oleh sekolah melalui aktifitas keseharian 


\section{IJER, 2 (1), 2017, 10}

lainnya yang terkait dengan lingkungan pada akhirnya akan menumbuhkan kesadaran di dalam diri para siswa bahwa lingkungan tempat mereka hidup adalah bagian tak terpisahkan dari mereka, para siswa akan menyadari pentingnya lingkungan dan betapa keberadaan para siswa sulit dibayangkan tanpa adanya lingkungan. Kesadaran timbal balik seperti inilah sesungguhnya yang telah membentuk karakter para siswa di Komunitas Belajar Qoryah Thayyibah.

Kelima, kegiatan yang dibarengkan dengan masa otientasi siswa (MOS) pada awal tahun pembelajaran ketika siswa baru pertamakali masuk sekolah adalah salah satnya membersihkan sampah di lingkungan luar sekolah. Siswa berkeliling kampung dan sambil mengenal keadaan nyata dari lingkungan yang akan mereka tinggali mereka wajib memungut sampah sampah yang mereka temuai sepanjang perjalanan mereka. Hal ini akan memberikan kesadaran kepada para siswa bahwa mereka meskipun hilir mudik di wilayah tersebut tetapi mereka tetap meningalkan jejak bersih. Lingkungan mendapatkan manfaaat dari keberadaan para siswa. Hal ini menumbuhkan karakter kuat pada diri para siswa terkait lingkungan dan hubungannya dengan manusia.

Komunitas Belajar Qoryah Thayyibah dalam konteks dakwah bil hal juga dengan dengan demikian telah berkontribusi positif terhadap penyadaran masyarakat akan pentingnya memelihara dan berinteraksi dengan lingkungan, hal ini diperlihatkan dan dicontohkan oleh sekolah Qoryah Thayyibah melalui aktifitas para siswa tersebut, disinilah aspek tidak langsung yang tanpa disadari telah dilakukan oleh sekolah Qoryah Thayyibah. Yaitu berdakwah dengan perbuatan atau dakwah bil Hal.

\section{Daftar Pustaka}

Ainurrofiq, D. (2003). Emoh sekolah, Yogyakarta: INSPEAL Ahimsakarya.

Bates. AW. (1995). Technology, open learning and Distance education, London: Routledge

Blumer, H. (1946) :Collective Behavior dalam Robert Mirsel: Teori pergerakan sosial. Yogyakarta: Resist Book Darmaningtyas. (1999). Pendidikan pada dan setelah krisis. Yogyakarta: Pustaka Pelajar.

Djohar. (2003). Pendidikan Strategik, alternatif untuk pendidikan masa depan. Yogyakarta: LESFI

Driyahara, N. (1980). Tentang Pendidikan, Kanisius, Yogyakarta.

Irwanto, Mau kemana Pendidikan Dasar kita ?, Kompas 12/05/05 dalam http://perpustakaan bapennas.go.id
Illich, I. (2000). Bebaskan masyarakat dari belenggu sekolah. Jakarta: Yayasan Obor Indonesia.

Mu'arif. (2005). Wacana Pendidikan Kritis, menelanjangi problematika, meretas masa depan pendidikan kita, Yogyakarta: IRCiSoD.

Mustakim, B. (2011). pendidikan karakter, membangun delapan karakter emas menuju indonesia bermartabat. Yogyakarta: Samudera Biru,

Nugroho, A. (2006) dalam Gugur Asem Pembangunan Kemiskinan, Bunga Rampai Pembangunan dan Kemiskinan. Jurusan Sosiatri Fisipol UGM. Yogyakarta: Aditya.

Satriago, H. (1996) Istilah lingkungan untuk manajemen. Jakarta : Ecolink, IPMI, dan Gramedia.

Sindhunata. (2000). Menggagas paradigma baru pendidikan. Yogyakarta: Kanisius.

Karakter (Terj.), Bumi Aksara, Jakarta, 2012,

Tjokrowinoto, M. (2002). Pembangunan dilema dan tantangan. Yogyakarta: Pustaka Pelajar http://www.pendidikan salatiga/qaryahtayibah http://www.kompas.com/kompas-cetak/didaktika 